Collection: 3rd International Elm Conference, Florence (Italy - 2013)

"The elms after 100 years of Dutch Elm disease"

Guest Editors: A. Santini, L. Ghelardini, E. Collin, A. Solla, J. Brunet, M. Faccoli, A. Scala, S. De Vries, J. Buiteveld

\section{Implementing the dynamic conservation of elm genetic resources in Europe: case studies and perspectives}

\author{
Eric Collin ${ }^{(1-3)}$, Michele Bozzano ${ }^{(2)}$
}

Many European countries have undertaken the static preservation of native elm genotypes in clone collections maintained ex situ. Less development has been devoted to the dynamic conservation of elm populations in situ. Case studies of elm conservation in France are given here as an illustration of methods employed at country level. We also briefly review the process used by the "European Forest Genetic Resources Programme" (EUFORGEN) to monitor elm dynamic conservation in a pan-European perspective. Dynamic conservation methods were promoted by EUFORGEN through leaflets, strategies, Technical Guidelines and the geo-referenced database EUFGIS on Dynamic Conservation Units (DCUs). Because the network of DCUs needs to be representative of the partitioning of adaptive diversity across the species distribution range, a GIS-aided approach has been developed to position DCUs in environmental zones and identify conservation gaps. The two DCUs of European white elm (Ulmus laevis Pall.) selected in riparian forests of two different climatic zones of France show that management oriented toward habitat protection is compatible with dynamic conservation, and that the species can still be conserved in situ in spite of Dutch Elm Disease (DED). Collaboration with habitat conservationists enabled the monitoring of losses to DED and the assessment of within-population diversity for flowering phenology. Collaboration with forest geneticists revealed that the diversity of the Garonne population was low, but that it contained rare DNA variants and adaptive traits. Since 1987, experimental restoration of countryside hedges has been carried out, using field elm clones (U. minor Mill.) selected from the French national collection and tested for lower susceptibility to the agent of DED in artificial inoculation tests. Such plantations can be viewed as a very dynamic form of conservation if they permit the local gene pool to be reinforced with trees able to reach sexual maturity and exchange pollen with elms in the neighborhood, hence contributing new genotypes that will be submitted to natural selection and provide fuel for ongoing adaptation processes. Initiatives assembling a large consortium of stakeholders, including habitat conservationists and hedge re-constructors, are needed to trigger new conservation projects.

Keywords: Elm, Ulmus minor, Dynamic Conservation, Population Genetics, Europe, France

\footnotetext{
Introduction

The devastating spread of Dutch Elm Disease (DED) in a country often triggers emergency conservation actions consisting of the preservation of clonal material (cuttings, grafts) in ex situ collections known as "clone archives" or "clone banks". However, static preservation approaches are not sufficient from an evolutionary perspective and need to be complemented with dynamic conservation methods (Collin et al. 2004). Such methods aim at facilitating the adaptation of the conservation populations, and the species
}

(1) Irstea, UR EFNO, Centre de Nogentsur-Vernisson F-45290 Nogent-sur-Vernisson (France); (2) EUFORGEN, Bioversity International, v. dei Tre Denari 472/a, I00057 Maccarese, Rome (Italy); (3) French Commission of Forest Genetic Resources, Ulmus spp. conservation programme

@ Eric Collin (eric.collin@irstea.fr) Received: Dec 19, 2013 - Accepted: Mar 05, 2014

Citation: Collin E, Bozzano M, 2015. Implementing the dynamic conservation of elm genetic resources in Europe: case studies and perspectives. iForest 8: 143-148 [online 2014-08-07] URL:

http://www.sisef.it/iforest/contents/? id $=$ ifor $1206-008$

Communicated by: Alberto Santini

phases. By maintaining a large number of flowering and seed-trees, and facilitating pollen and seed production, managers can combat diversity-reducing evolutionary forces (genetic drift, inbreeding). By maintaining corridors and using restoration ecology methods in fragmented populations, they can facilitate gene flow, which is a strong evolutionary force for increasing diversity.

Herein, we summarize the process followed by the "European Forest Genetic Resources Programme" (EUFORGEN) to monitor the progress of dynamic conservation of elm and other forest tree genetic resources (FGR) at pan-European level. Using the case study of the European white elm (Ulmus laevis Pall.) in France, we also give an illustration of dynamic conservation methods employed at country level. Finally, we briefly discuss the possible links between restoration and $\mathrm{dy}$ namic conservation (case of field elm, $U$. minor Mill., plantations in France) and the need to build a large consortium of stakeholders to trigger new implementation efforts.

\section{Promoting and monitoring} dynamic conservation in a panEuropean perspective

\section{Promoting European conservation}

strategies and assembling conservation data ging environment (e.g., climate, diseases). Dynamic conservation requires active population management actions promoting natural selection, which is the "engine" of the adaptation process, and sufficient withinstand genetic diversity, which is the "fuel" needed in this process. Consequently, management measures in Dynamic Conservation Units (DCUs) not only entail dynamic silviculture to speed-up regeneration turn-over but also a special attention to genetic diversity, particularly in the stand regeneration
The dynamic conservation of elm genetic resources was promoted by EUFORGEN through a dedicated Ulmus species strategy (Collin 2002) and a "Technical Guidelines" six-page leaflet devoted to the conservation of Ulmus laevis Pall. (Collin 2003).

More generally, EUFORGEN has defined methods and created a geo-referenced database to monitor the progress of dynamic conservation of FGR in Europe. Before 2011, it was difficult to pool information 


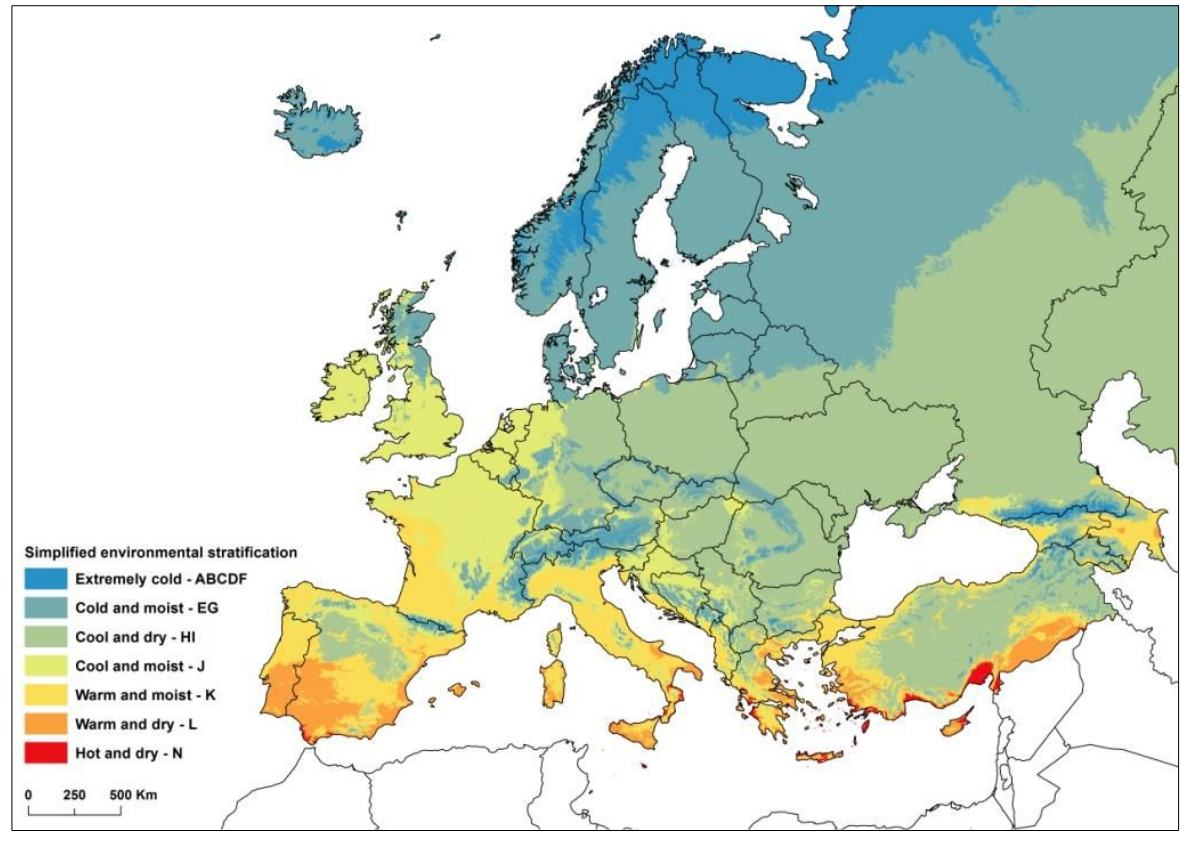

Fig. 1 - Simplified environmental stratification of Europe (adapted from Metzger et al. 2013). Zone M (for Canary Islands) is not shown on the map.

from over 30 European countries and make a complete picture of "what was conserved where and how". Availability and quality of data was a problem, and there were different opinions between countries about the definition and management rules of DCUs. The European project "Establishment of a European Information System on FGRs" (EUFGIS, April 2007-March 2011) has permitted definitions to be clarified and technical pro-

blems solved. The project was co-funded by the European Commission and coordinated by Bioversity International. Its key results are: (i) definition of minimum requirements and data standards for DCUs; (ii) creation of an online geo-referenced database (http://por tal.eufgis.org); (iii) establishment of a network of National Focal Points in 36 European countries; and (iv) publication of case studies (Lefevre et al. 2013).

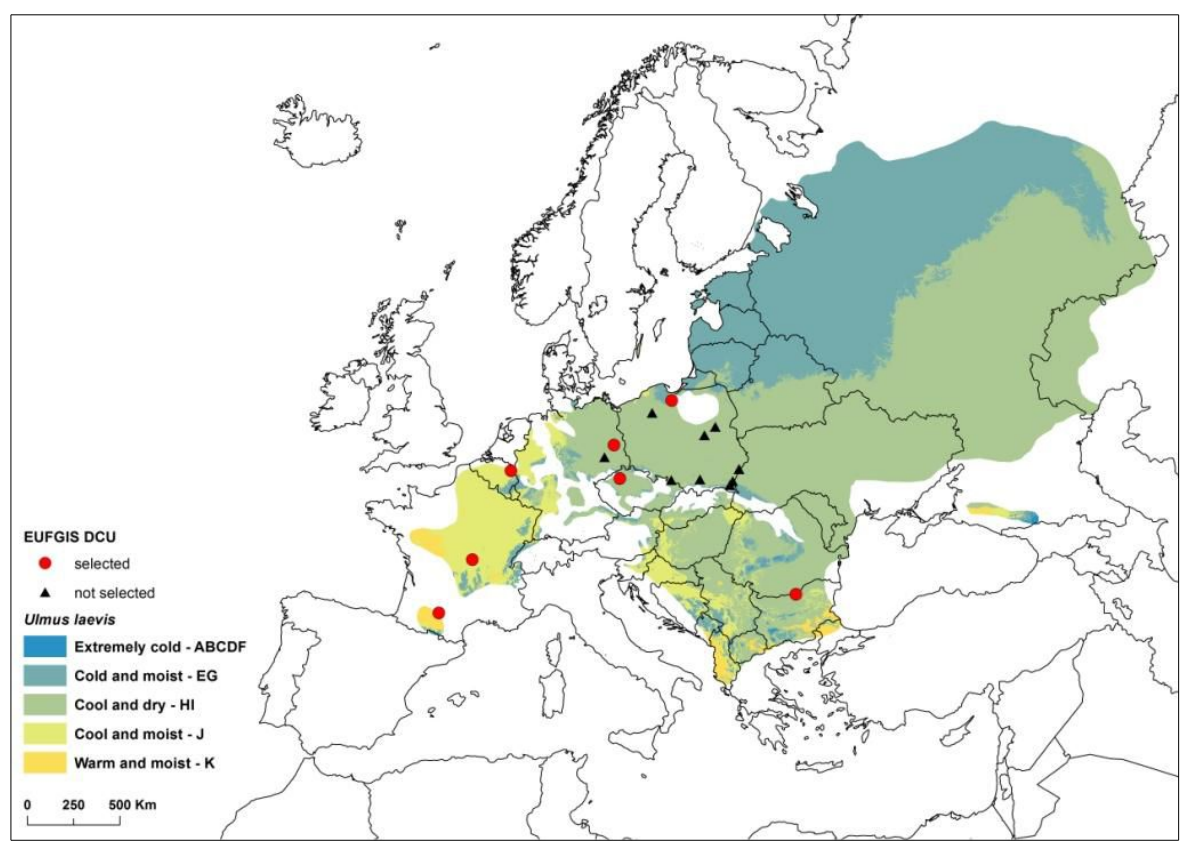

Fig. 2 - Ulmus laevis distribution range, Dynamic Conservation Units and environmental zones adapted from Metzger et al. 2013. (red dots): DCUs selected for the Core European network; (black triangles): other DCUs.
Minimum requirements for DCUs include various criteria: biological (a minimum number of reproducing trees), legal (have a designated status as an FGR conservation area at national level) and management (be managed for the genetic conservation of one or several target tree species, be monitored regularly - Koskela et al. 2013).

Whereas the static preservation of elm clones has already been carried out in many European countries, the low number of DCUs entered by the National Focal Points in the EUFGIS database shows that efforts are still needed for successful dynamic conservation. In September 2013, the number of DCUs was 27 in seven countries for the wych elm (Ulmus glabra Huds.), 17 in six countries for the European white elm and only two in two countries for the field elm.

\section{Identifying dynamic conservation gaps at a pan-European level}

In 2011, a EUFORGEN working group was created to define methods for assessing progress in dynamic conservation and to identify gaps in the network of conservation units. Considering that a conservation priority was the adaptive diversity of forest trees throughout their distribution ranges, the working group proposed that a climatic zoning of Europe could be used as a proxy for characterizing the diversity conserved in the DCUs across the continent. With some simplifications, the global environmental stratification of Metzger et al. (2013) was considered an appropriate climatic zoning for the purpose of the working group, and the 14 zones defined by Metzger et al. for Europe were conveniently aggregated into seven (Fig. 1), plus one specific to the Canary Islands. In the case of U. laevis, the species distribution area appeared to stretch over five environmental zones, out of which four are represented in DCUs (Fig. 2). However, the distribution range of $U$. laevis needs to be revised, adding recently discovered marginal populations (Fig. 3).

Gaps in conservation efforts were identified based on country borders and climatic zones within each country (country $\mathrm{x}$ zone). The country $\mathrm{x}$ zone within the distribution range of the species where there are no conservation units, represents the gaps in conservation efforts. The establishment of new units is a national responsibility. Furthermore, the working group applied a systematic approach to select one conservation unit in each country $\mathrm{x}$ zone at the pan-European level for the establishment of a core network of dynamic conservation units. The EUFORGEN National Coordinators and the EUFGIS National Focal Points will be asked to comment on the selection of the units in their country and will have an opportunity to propose changes. Additional conservation units covering migration routes, refugial 
areas and contact zones between migration routes can be selected for the core network, once this information is available (de Vries et al. 2013)

\section{Practical implementation of dynamic conservation at country level}

Case study: selection and monitoring of DCUs of U. laevis in France

The French policy for the conservation of FGR is defined and financed by the ministry of agriculture flanked by the scientific expertise of the "Commission of Forest Genetic Resources" (CRGF). A conservation programme combining ex situ and in situ methods has been set up for the three native European elm species (Collin 2001). As regards the dynamic conservation of the white elm, priority was given to resources of interest to a pan-European perspective, i.e., populations at the southern margin of the species distribution area and/or possibly possessing some interesting adaptive diversity traits (e.g., adaptation to the warm climate of southwest France). Consequently, despite the fact that $U$. laevis is naturally distributed in the Rhine valley and northeast France in general, DCU selection efforts were targeted on two western hydrographic zones of France, the Loire and the Garonne basins (Fig 4). Subsequent conservation priorities wil focus on the southern part of the Rhône basin, where $U$. laevis is extremely rare, and the Seine basin where the species is naturally distributed in small fragmented populations.

When selecting DCUs, particular attention was given to population size (at least 50 reproducing trees) and its capacity to survive and regenerate in spite of DED pressure. Other requirements were that ownership and status would permit active management and that local managers were willing to contribute to the monitoring of the target species population. Conversely, no strong requirement was made for the autochthony of the population, because this criterion is difficult to evaluate in many cases, and also because a well adapted genetic resource at the margin of the species distribution area is a valuable resource, even if its autochthony is uncertain.

Two DCUs of $U$. laevis have been approved by the CRGF commission and entered into the EUFGIS database: the "Val d'Allier" DCU in the Loire basin, and the "Ramier de Bigorre" DCU in the Garonne valley. The former was preferred to other candidate DCU populations because its whole area is state owned and managed for nature conservation. The latter was the only large population inventoried in the Garonne valley, and its management and monitoring are also very good. Its autochthony is not consistent with Atlas Florae Europaeae (Jalas \&

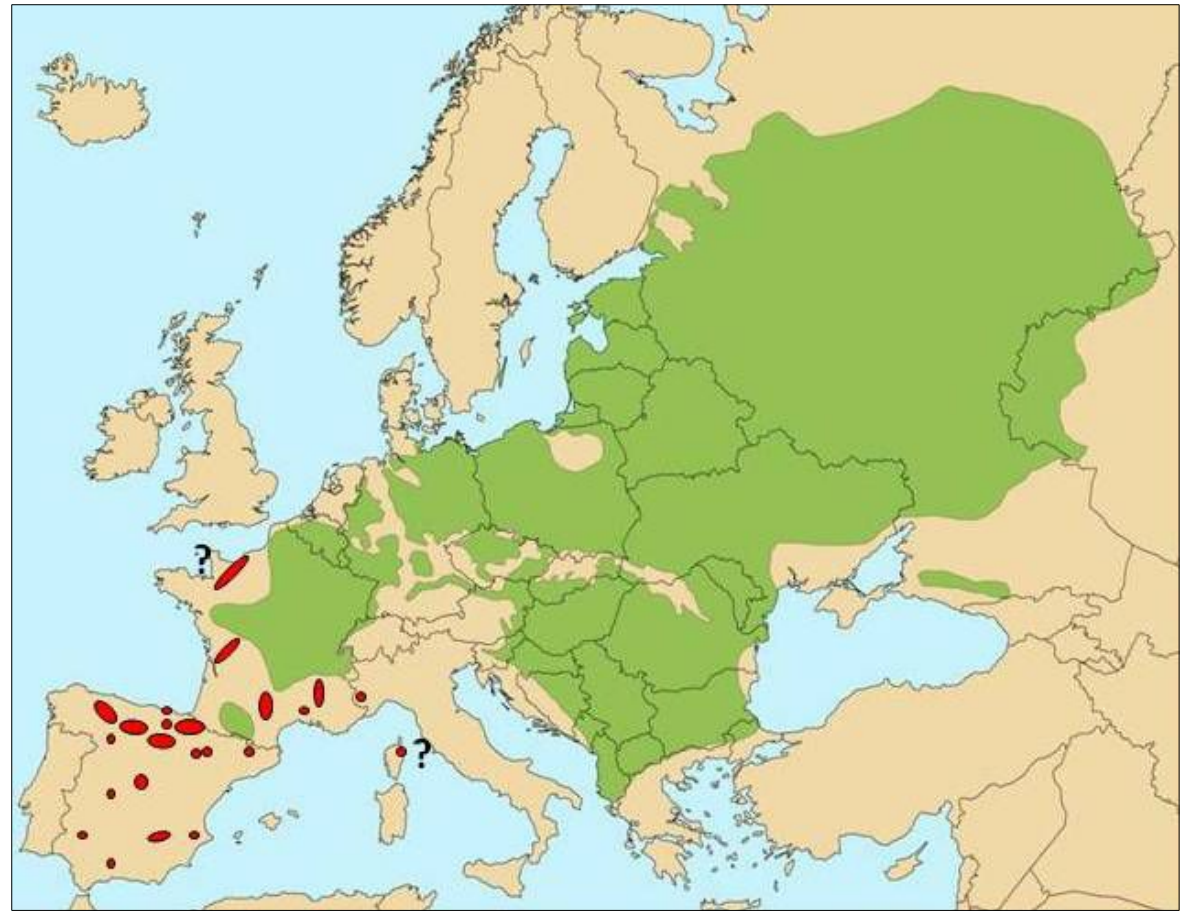

Fig. 3 - Need for the revision of the distribution map of Ulmus laevis. (red dots): recently discovered populations

Suominen 1976), but seems possible according to Schmucker (1942). Moreover, a study of chloroplast DNA markers carried out with B. Demesure-Musch (Office National des Forêts, Orleans) on 67 leaf samples originating from southwest France showed that 10 samples had a rare cpDNA type which was found neither in the rest of France, nor in Belgium and Germany (Cemagref, Final report DERF 02/98, 2000). Further molecular research showed that this rare haplotype exists also in Spain, suggesting that the Spanish and southwest France populations are autochthonous and possibly originate from a refugium in the Pyrenees (FuentesUtrilla et al. 2014).

\section{Description and monitoring of the "Ramier de Bigorre" DCU}

The DCU stretches over $6 \mathrm{~km}$ along the Garonne River and covers about 118 ha of remnants of the original riparian forest, which has been destroyed and fragmented for agriculture and poplar cultivation (Fig. 5). It is composed of two major subpopulations, comprising over 700 white elms with a

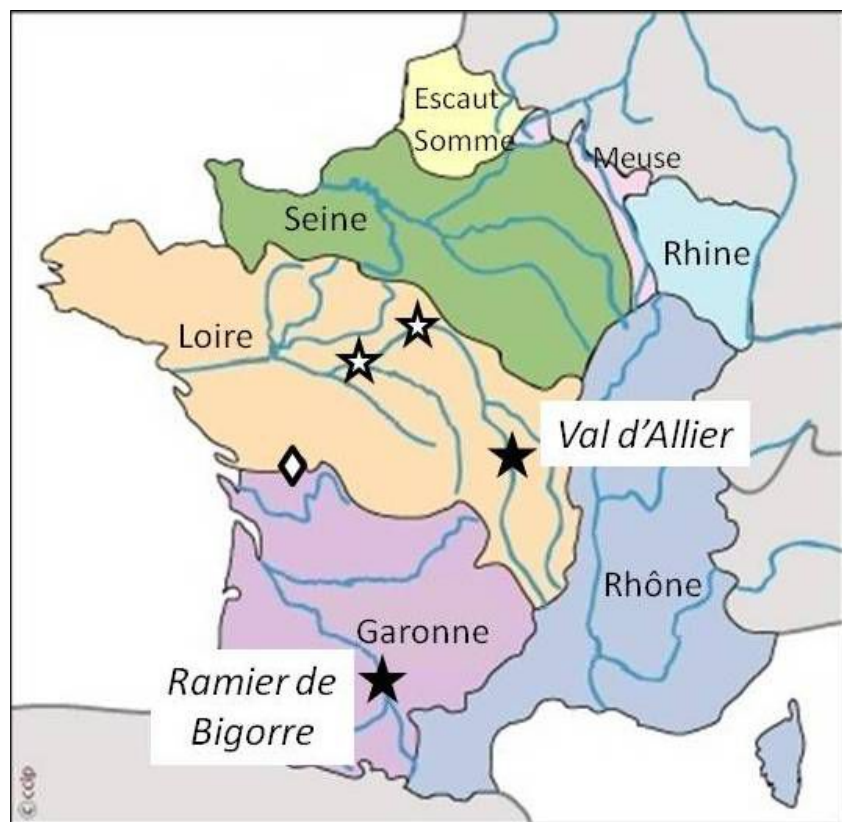

Fig. 4 - Selection of Dynamic Conservation Units in two different hydrographic zones of France. (black stars): selected DCUs; (white stars): unselected candidate-DCU populations; (diamond): conservation ongoing out of DCU selection process. 
Fig. 5 - Localization of "Ramier de Bigorre" Dynamic Conservation Unit. (red lines): borders of the DCU four subpopulations; (grey zones): urban areas (including suburbs of Toulouse)

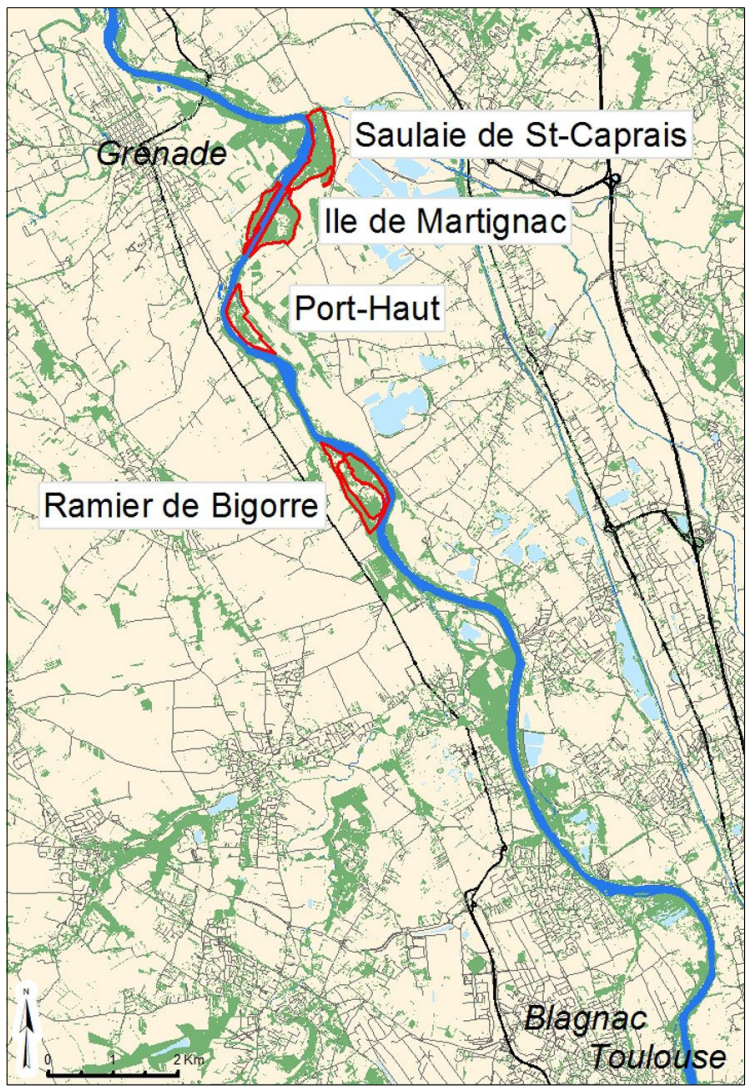

diameter at breast height (DBH) exceeding 5 $\mathrm{cm}$, and complemented with two other woodlands where a few scattered white elms can contribute gene flow to the main subpopulations. Some more U. laevis trees can also be found upstream of the DCU, in the rare wooded areas left between the DCU and the suburbs of Toulouse.

An inventory and the durable labelling of the large white elms (diameter over $20 \mathrm{~cm}$ ) was carried out in 2000 in the two major subpopulations, in order to enable the monitoring of tree mortality and the identification of trees sampled for genetic studies and/or seed harvest. A new inventory was carried out when the metal labels had to be replaced in 2012 , revealing no mortality caused by DED on the labelled trees of one subpopulation and rare losses in the other. Some mortality was also caused by DED on smaller, unlabelled, white elms. In spite of those losses and DED symptoms on other trees, the capacity of the $U$. laevis population to survive and regenerate was not considered seriously challenged by DED pressure.

The genetic diversity study of several European U. laevis populations was carried out by Rachel Whiteley in the frame of her $\mathrm{PhD}$ thesis (Whiteley 2004). Most of the samples representing the Garonne provenance were taken in the "Ramier de Bigorre" DCU or neighbouring woodlands; 18 trees were included in the nuclear DNA microsatellite study, and 19 families in the adaptive cha- racters study. The Garonne provenance was compared to central (Germany), Nordic (Sweden) and eastern (Moscow) populations. The results of the molecular studies and common garden experiments by Whiteley reinforce the reasons for conserving the Garonne genetic resource: (i) a rare cpDNA type exists in the Garonne population; and (ii) bud set is later in the Garonne population. The lower mean allelic richness of the Garonne population was however indicative of possible risks of genetic drift. Such concern fully confirms the method employed in 2001, when a restoration plantation was carried out in a sector of the DCU invaded by Acer negundo L. The 129 U. laevis seedlings used in this plantation were representative of 19 half-sib families originating from different places of the DCU and neighbouring woodlands; the plants of the different families were randomly distributed over the plantation area.

Description and monitoring of the "Val d'Allier Nature Reserve" DCU

The DCU stretches over $20 \mathrm{~km}$ along the Allier River, a major tributary of the Loire with very active hydro-sedimentary dynamics. It covers about 200 ha of riparian forest dominated by the black poplar (Populus nigra L.) and the white willow (Salix alba L.), and contains a large, young population of $U$. laevis. About 540 white elms with a DBH exceeding $5 \mathrm{~cm}$ were inventoried in
2003 , with only 20 over $30 \mathrm{~cm}$ and only one over $60 \mathrm{~cm}$. The population was generally less than 30 years old, and never more than 50. More white elms, including large ones, can be found in neighbouring areas of the floodplain as well as upstream of the DCU.

There is no clear explanation for the relatively recent and rapid development of $U$. laevis in the DCU, but hydrologic factors and the reduction of the rabbit population on the river banks may have played a role.

To monitor the abundance of flowering and fructification, and the impact of DED in the population, a sample of 98 trees was selected in 2004 in different sectors of the DCU. Protocols for scoring flowering stages (Fig. 6) and estimating seed abundance as well as

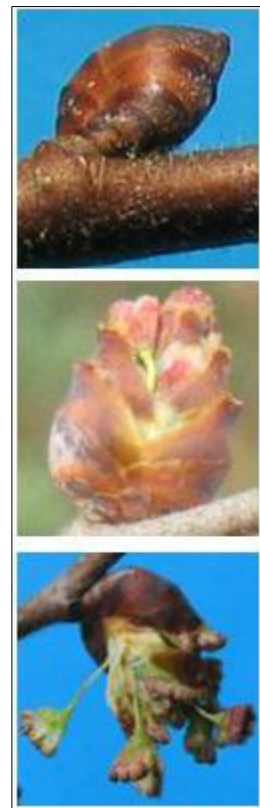
bud is closed
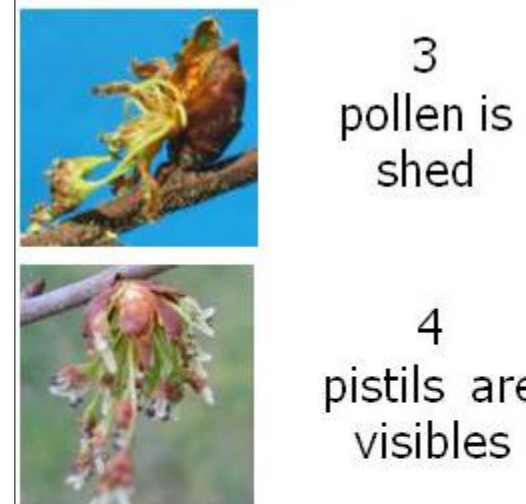

peduncules are visible

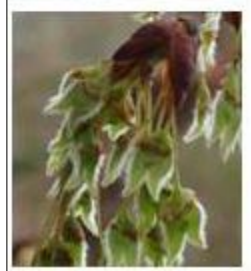

5

pistils are visibles

Fig. 6 - Scoring protocol for the monitoring of flowering phenology. 
Tab. 1 - Monitoring of flowering and fructification abundance and quality in "Val d'Allier Nature Reserve" DCU. (1): Number of flowering trees in the 98 tree sample, regardless of flower abundance per tree; (2): Mean fructification abundance per seed-bearing tree $(100 \%=$ tree full of seed; $5 \%=$ seed on one branch only); (3) Mean percentage of full seed.

\begin{tabular}{|c|c|c|c|}
\hline Year & $\begin{array}{l}\text { Flowering } \\
\text { trees }{ }^{(1)}\end{array}$ & $\begin{array}{l}\text { Fructification } \\
\text { abundance }^{(2)}\end{array}$ & $\begin{array}{c}\text { Full } \\
\text { seed }^{(3)}\end{array}$ \\
\hline 2004 & $90 \%$ & - & $49 \%$ \\
\hline 2005 & $100 \%$ & $65 \%$ & $71 \%$ \\
\hline 2006 & $93 \%$ & $39 \%$ & $60 \%$ \\
\hline
\end{tabular}

full-seed percentages were established by scientists with the local managers in charge of the surveys and the collection of seed lots Results of three monitoring campaigns (2004-2006) revealed some diversity in flowering phenology within and between geographic sectors, up to a 10-day lag between trees. Percentages of flowering trees, fructification abundance and full seed were found to be good to excellent every year (Tab. 1 Collin et al. 2009). The impact of DED was assessed in the same period and in January 2014, totaling 27 losses (28\%) in 10 years. The survival and regeneration capacity of the $U$. laevis population was not judged to be clearly endangered, but the pathologic pressure was found worryingly strong in some sectors. Regeneration was not monitored precisely but considered low. In collaboration with the Research Institute for Nature and Forest (INBO, Flanders, Belgium), the geographical partitioning of neutral genetic diversity was investigated on a subsample of 45 trees characterized with molecular markers (AFLPs), revealing that one sector is distinct from the other sectors in the sample (Cox, INBO report 2012).

\section{Concluding remarks and perspectives}

The implementation of elm genetic resources dynamic conservation has markedly progressed in the last decade but EUFGIS data analysis shows huge conservation gaps and suggests that considerable efforts are still needed for the selection of DCUs of native European elm species across their natural ranges. This is the case for $U$. laevis at the southern and northern margins of the species range, although rapid improvement is expected at the south margin as an outcome of the conservation programmes deployed in Spain (Venturas et al. 2014) and starting in Italy (Pepori et al. 2013). This is also the case for $U$. glabra in the southern and western parts of its range. The situation for $U$. minor needs to be discussed more specifically because of the extremely low number of DCUs (only two) in the present state of the conservation network. Three reasons are likely to explain the lack of interest for the in situ conservation of $U$. minor populations: (i) conserving mature trees is considered impossible be- cause the species hardly ever escapes and survives contamination by DED; (ii) genetic conservation occurs naturally through roots suckers and seedlings; (iii) U. minor genetic resources are maintained in ex situ clone banks. In spite of these reasons and the impossibility of combating the continuous pressure of DED, selecting DCUs in large riparian natural populations of $U$. minor would facilitate the monitoring and protection of regeneration. Even more dynamic conservawhere $U$. minor has been cultivated for centuries as a major part of the landscape, particularly in countryside hedges between fields and along paths and ditches. In such cases, dynamic conservation measures could depart from the clear strategy and in situ methods defined in the EUFGIS project, and blur the differences between in situ and ex situ conservation strategies.

\section{From dynamic conservation to}

"dynamic restoration": the case of field elm hedgerows in France

Dynamic conservation is generally understood as a form of in situ conservation clearly separated from restoration and ex situ approaches, and planting low diversity allochthonous material in endangered populations is clearly not a recommended conservation option. The case is however different when landscape restoration is carried out with large diversity plant material originating from the same region and climatic zone. Such restoration actions can be viewed as an extremely dynamic way of reinforcing the local gene pool, even if the wording "conservation" is rejected or questioned for such courses of action. "Dynamic restoration" may become an increasingly useful tool for FGR conservation in the future, especially in the context of climate change.

An illustration of very dynamic use of conservation material can be found in the case of the field elm reintroduction experiments carried out in local programmes on field hedge reconstruction in different parts of France. Plantations are realized with native $U$. minor clones selected in the national collection for their better tolerance to the agent of DED in artificial inoculation tests (i.e., compared with other native elm material). tion measures could be employed in areas
The elms are planted among other tree and shrub species, with at least five ramets per elm clone in randomized single tree plots. These kinds of plots enable an evaluation of the field tolerance of the planted material and also facilitate cross-pollination between clones. Owing to their relatively good tolerance to DED, some of the planted elms are likely to live long enough to produce flowers and exchange pollen with other elms in the plantation and also in their neighborhood, hence contributing seedlings (i.e., new genotypes) that will be submitted to natural selection and provide fuel for ongoing adaptation process. Consequently, the network of plantation plots created in the frame of the elm conservation programme serves both the field experimentation and the dynamic conservation purposes at the same time.

Perspectives: towards a consortium for elm dynamic conservation

Implementing the dynamic conservation of elms remains a national responsibility, but projects are more likely to be launched when they receive international support, e.g., co-financing by the European Commission. Consequently, a consortium of scientists (geneticists, ecologists), land managers (farmers, conservationists, foresters) and other stakeholders (nursery managers, seed merchants) is needed to set up projects. The participation of EUFORGEN in such a consortium would ensure the coordination of actions from a pan-European perspective and facilitate the dissemination of project results.

\section{Acknowledgements}

The authors thanks the following people: Arwen Bailey (Bioversity, Rome) for the linguistic revision of the manuscript; Laurent Velle and Pierre-André Dejaifve (R.N. Val d'Allier, France); Michèle Jund, Jacques Rhodes, Florent Craipeau, Philippe Caniot, Jérôme Segonds, Pascale Mahé (NatureMidi-Pyrénées, France); Fédéric Coulon (Solagro, France); Michel Rondouin (Office National des Forêts-PNRGF Guémené-Penfao, France); Cécile Joyeau, Catherine Menuet, Stéphane Matz, Clément Pichot, Charly Bourriaux, Mathieu Rubenstein, Damien Davy (Irstea); and All EUFGIS National Focal Points.

The EUFGIS project (AgriGenRes 009) was co-funded by the European Commission (DG Agriculture and Rural Development). The conservation actions were co-funded by the Ministry of Agriculture, DGPAAT (France) and the "Plan Loire Grandeur Nature" (France).

EC is the Coordinator of the Ulmus spp. conservation programme of the French Commission of Forest Genetic Resources (Commission des Ressources Génétiques Forestières), http://agriculture.gouv.fr/conservationdes-ressources. 


\section{References}

Collin E (2001). Stratégies pour la conservation in situ des ressources génétiques des ormes forestiers [Strategies for the in situ conservation of the genetic resources of forest elms]. Revue Forestière Française 53: 125-132. [in French] doi: $10.4267 / 2042 / 5284$

Collin E (2002). Strategies and guidelines for the conservation of the genetic resources of Ulmus spp. In: "Noble Hardwoods Network, Report of the fourth and fifth meetings, Sept. 1999 and May 2001" (Turok J, Eriksson G, Russel K, Borelli S eds). International Plant Genetic Resources Institute, Rome, Italy, pp. 50-67.

Collin E (2003). Technical guidelines for genetic conservation of the European white elm (Ulmus laevis Pall.). International Plant Genetic Resources Institute, Rome, Italy, pp. 6.

Collin E, Rusanen M, Ackzell L, Bohnens J, De Aguiar A, Diamandis S, Franke A, Gil L, Harvengt L, Hollingsworth P, Jenkins G, Meier Dinkel A, Mittempergher L, Musch B, Nagy L, Paques M, Pinon J, Piou D, Rotach P, Santini A, Vanden Broeck A, Wolf H (2004). Methods and progress in the conservation of elm genetic resources in Europe. Investigacion Agraria: Sistemas y Recursos Forestales 13: 261-272.

Collin E, Chantereau M, Velle L, Dejaifve PA (2009). Conservation de populations d'orme lisse (Ulmus laevis Pall.) en Val de Loire et Val d'Allier: rapport final "Plan Loire Grandeur Nature" [Conservation of White elm populations (Ulmus laevis Pall.) in Val de Loire and Val d'Allier. Final report of "Plan Loire Grandeur Nature"]. Cemagref, Nogent/Vernisson, France, pp. 15. [in French]

de Vries SMG, Alan M, Bozzano M, Burianek V, Collin E, Cottrell J, Ivankovic M, Kelleher CT, Koskela J, Rotach P, Vietto L, Yrjänä L (2013).
Pan-European strategy for genetic conservation of forest trees: establishment of a core network of dynamic conservation units. Working Group report, EUFORGEN, Bioversity International, Rome, Italy, pp. 18

Fuentes-Utrilla P, Venturas M, Hollingsworth PM, Squirrell J, Collada C, Stone GN, Gil L (2014). Extending glacial refugia for a European tree: genetic markers show that Iberian populations of white elm are native relicts and not introductions. Heredity 112: 105-113. - doi: $10.1038 /$ hd y.2013.81

Jalas J, Suominen J (1976). Atlas florae europaeae. Distribution of vascular plants. The Committee for Mapping the Flora of Europe and Societas Biologica Fennica, Vanamo, Helsinki, Finland, vol. 3, pp. 128

Koskela J, Lefevre F, Schueler S, Kraigher H, Olrik DC, Hubert J, Longauer R, Bozzano M, Yrjana L, Alizoti P, Rotach P, Vietto L, Bordacs S, Myking T, Eysteinsson T, Souvannavong O, Fady B, De Cuyper B, Heinze B, von Wuhlisch G, Ducousso A, Ditlevsen B (2013). Translating conservation genetics into management: pan-European minimum requirements for dynamic conservation units of forest tree genetic diversity. Biological Conservation 157: 39-49. - doi: 10.10 16/j.biocon.2012.07.023

Lefevre F, Koskela J, Hubert J, Kraigher H, Longauer R, Olrik DC, Schueler S, Bozzano M, Alizoti P, Bakys R, Baldwin C, Ballian D, BlackSamuelsson S, Bednarova D, Bordacs S, Collin E, De Cuyper B, De Vries SMG, Eysteinsson T, Frydl J, Haverkamp M, Ivankovic M, Konrad H, Koziol C, Maaten T, Paino EN, Ozturk H, Pandeva ID, Parnuta G, Pilipovic A, Postolache D, Ryan C, Steffenrem A, Varela MC, Vessella F, Volosyanchuk RT, Westergren M, Wolter F, Yrjana L, Zarina I (2013). Dynamic conservation of forest genetic resources in 33 European countries. Conservation Biology 27: 373-384. - doi: 10.1111/j.1523-1739.2012.01961.x

Metzger MJ, Bunce RGH, Jongman RHG, Sayre R, Trabucco A, Zomer R (2013). A high-resolution bioclimate map of the world: a unifying framework for global biodiversity research and monitoring. Global Ecology and Biogeography 22 : 630-638. - doi: 10.1111/geb.12022

Pepori AL, Selvaggi A, Varese P, Ghelardini L, Santini A (2013). About Ulmus laevis Pal. in Italy. In: Proceedings of the " 3 rd International Elm Conference. The elm after 10 years of Dutch elm disease" (Manzo R ed). Florence (Italy) 9-11 October 2013. IPP-CNR, Florence, Italy, pp. 39. [online] URL: http://elm2013.ipp.cnr.it/downlo ads/book_of_abstracts.pdf

Schmucker T (1942). La distribution des espèces arborescentes de la zone septentrionale tempérée [The tree species of the Northern temperate zone and their distribution]. Silvae Orbis 4, Centre International de Sylviculture, Berlin-Wannsee, Germany. [in French]

Venturas M, Fuentes-Utrilla P, López R, Perea R, Fernández V, Gascó A, Guzmán P, Li M, Rodríguez-Calcerrada J, Miranda E, Domínguez J, González-Gordaliza G, Zafra E, Fajardo-Alcántara M, Martín JA, Ennos R, Nanos N, Lucena JJ, Iglesias S, Collada C, Gil L, (2014). Ulmus laevis in the Iberian Peninsula: a review of its ecology and conservation. iForest (early view): e1-e8. - doi: 10.3832/ifor1201-008

Whiteley R (2004). Quantitative and molecular genetic variation in Ulmus laevis Pall. Ph.D. Thesis, Department of Plant Biology and Forest Genetics, Swedish University of Agricultural Sciences, Uppsala, Sweden, pp. $33+$ Appendix. 